\title{
Will there ever be peace in Europe?
}

\author{
Settling Yugoslavia's tribal wars is an urgent need, but in the long run Europe must trade cultural diversity for \\ economic development away from its agrarian roots.
}

SiNCE the time of Charlemagne, Europe has been a turbulent place. The only comfort is that it was even worse before: the Roman Empire was never as stable and prosperous as its contemporary apologists would have had the rest of us believe. The swashbucklers who built that empire took it as their first task in newly occupied parts of Europe to pacify the warring tribes that had previously been in charge; Tacitus tells the tale well in respect of Britain. Rarely did they succeed entirely. Indeed, the post-Roman history of Europe has been one of continuous tribal conflict, complicated by the frequent invention of new tribes (such as the Normans, itinerant warlords with Scandinavian origins) and moderated occasionally by the temporary emergence of central authority - the Holy Roman Empire, the Napoleonic regime and the Stalinist recipe that kept the tribes of Central Europe at peace for 70 years in some cases, and since 1945 in the swathe of land from the Baltic to the Mediterranean, in the Adriatic and Aegean.

So what can hold the old tribal rivalries in check now that the stabilizing recipe has been abandoned and discredited? Events of the past few months in Yugoslavia point to the need for cement of another kind. But hankerings after the late Marshal Tito's recipe for stability would serve no purpose. The tragic warfare of the past several months, first in Croatia and now in Bosnia, shows that Tito's illusion of stability did nothing to blunt the edge of tribal rivalry in the Balkans but instead, by suppression, may have aggravated it. But the Serbian (and also Croatian) euphemism for justifying land-grabbing that turns peaceable people into refugees - 'ethnic cleansing' is the phrase - is such a painful echo of other recent abominations, by Stalin as well as Hitler, that the rest of Europe should be thoroughly alarmed, perhaps even up in arms.

Yet much of Europe is indifferent to what is happening in ex-Yugoslavia. To be sure, the United Nations peacekeeping force, largely Canadian by nationality but with significant French support, is now trying to police in Bosnia, as it tried in Croatia, cease-fire agreements that are broken as soon as they are supposed to operate. There are also negotiations in prospect, an outcome of the European Communities' (EC's) uncertain initiative, whose chief outcome so far has been Lord Carrington's long tally of broken cease-fire agreements. But Germany, which helped to precipitate the trouble by its over-hasty recognition of Slovenia last December, is unlikely to win much response to its plea for help with refugees, of whom it has taken
200,000 so far. (The irony is that in the long run it may not matter much; if granted asylum under German law, refugees from Yugoslavia will be free to live wherever they can find jobs in the EC.

What the rest of Europe must now do is to settle on a policy on Yugoslavia if a brokered peace, the best solution, does not emerge from the current London talks. The starting point should be a recognition that even governments have no right to turn people out of their homes because their language or their religion does not match their neighbour's, and that these despicable practices, by Croats as well as Serbs, are an offence against European civility that cannot be hidden by the pretence that either Yugoslavia or its components are sovereign states. Military intervention would probably be ineffectual, but is probably not necessary. Europe has not yet tried the concerted political pressure it could exert, and the effective sanctions that could follow. It would help enormously to engender sobriety in Bosnia if there were a public dossier of those known to be responsible for atrocities against the time when parts of Yugoslavia will wish to rejoin the wider European community.

That is a short-term strategy. How is Europe to bury the more durable tribal rivalries represented by Ulster, the continuing trouble over the Basque region of Spain and the impending secession of Slovakia from Bohemia and Moravia? For all of Europe's boast that it embodies a continental culture, too much of it is trapped in an agrarian way of life, which makes for an immobile population and the exaggeration of linguistic and other cultural differences. Thus the long-term remedy must be economic development away from agriculture - Europe can overfeed itself easily - and a wider economic union, which is the case for enlargement of the EC. But would that not diminish the cultural diversity of Europe? Those who make that argument an absolute should ask people who live in Bosnia what diversity has done for them.

\section{Notice to contributors}

So as to speed the handling of original research, contributors of articles are asked, please, to send five (not four) copies of manuscripts intended for publication and two copies of covering letters. Those who submit manuscripts by fax should send four copies by mail in the usual way. 